\title{
Din Eksenli Tüketimin Yeni Medyadaki Görünümleri: Tüketim Kültürü Bağlamında Bir Değerlendirme*
}

\author{
Didem GAZNELi** \\ Nilgün SOFUOĞLU KILIÇ***
}

Öz

Medya, piyasa mantığının korunup üretilmesine aracılık ederken, tüketim ideolojisinin kitleler tarafından kolayca benimsenmesine de neden olmaktadır. Böylece medya, pek çok şey gibi dini değerlerin de metalaştırımasının en çarpıcı alanlarından biri haline gelmektedir. Bununla birlikte medyanın, sadece dini anlam ve sembolleri birer tüketim nesnesine indirgemekle kalmadığı; aynı zamanda, dindar bireyin kimlik ve yaşam tarzının yeniden inşa edilme sürecinde aktif bir rol oynadığı da gözlemlenmektedir. Son yıllarda, değerlerin ve öznenin bizatihi kendisini tükettiği tartışmaları dikkate alındığında, medya ve din çalışmalarında tüketim meselesinin daha geniş kapsamlı ele alınması gerektiği anlaşılmaktadır. Bu makalede yeni medyaya yansıyan söz konusu görünümlere ilișkin gözlemler, ilgili literatürle bir araya getirilerek tartışılmakta; böylece gözlem ve literatür taraması yöntemleri kullanılarak sosyolojik bağlamın tespiti amaçlanmaktadır. Çalıșma, medyanın, kapitalist sistemin değerlerini merkeze yerleștirerek dinsel olanı da tüketimin konusu haline getirdiği ve böylece medya, din ve tüketim kültürü etkileşiminin, bireylerin kimlik ve yaşam tarzlarındaki değişimi kaçınılmaz kıldığı sonucunu göstermektedir.

Anahtar Kelimeler: Yeni Medya, Medya, Din, Dini Değerler, Tüketim Kültürü, Metalaşma

\section{Appearances of Religion-Based Consumption in the New Media: An Assessment in the Context of Consumption Culture}

\begin{abstract}
While the media mediates the preservation and production of the logic of the market, it also causes the consumption ideology to be easily adopted by the masses. Thus the media becomes one of the most striking areas of the commodification of religious values as well as many things. However, the media does not merely reduce religious meanings and symbols to consumption objects; at the same time, it is observed that the religious individual plays an active role in the process of reconstructing the identity and lifestyle. In recent years, considering the debates on the consumption of values and the subject's own self, there is a need for a broader discussion of the consumption issue in media and religion studies. In this article, the views reflected in new media are brought together with the relevant literature and discussed, and thus the sociological context is aimed to be determined. The study shows that the media puts the values of the capitalist system at the center, making the sacred the subject of consumption and thus the inevitability of change in the interaction between religion and culture.
\end{abstract}

Keywords: New Media, Media, Religion, Religious Values, Consumption Culture, Commodification

ATIF: Gazneli, D. ve Sofuoğlu Kılıç, N. (2020). Din eksenli tüketimin yeni medyadaki görünümleri: Tüketim kültürü bağlamında bir değerlendirme. Medya ve Din Araştırmaları Dergisi (MEDiAD), 3(2), s. 191-216.

\footnotetext{
* Bu çalıșma Didem Gazneli'nin, Nilgün Sofuoğlu Kılıç danışmanlığında “Tüketim Toplumu Bağlamında Türkiye'de Yeni Medyanın Muhafazakarlığın Dönüşümü ve Dini Değerlerin Metalaşması Üzerine Etkisi” (Adnan Menderes Üniversitesi, 2020) başlıklı yüksek lisans tezinden üretilmiştir.

** Doktora Öğrencisi, İzmir Bakırçay Üniversitesi, e-mail: didem_gazneli@outlook.com | orcid.org/0000-00027541-5505

*** Dr. Öğr. Üyesi, Adnan Menderes Üniversitesi, e-mail: nilgun.sofuoglu@adu.edu.tr| orcid.org/0000-00028304-9883
} 


\section{Giriş}

Kitle iletişim araçlarının gelișmesi, dini yașayıș biçimlerini etkilemiștir. Medya ile din arasındaki ilişkinin, bireylerin düşünce ve davranış biçimlerinde önemli etkiler yarattığı ve mevcut değerleri de medyanın kuralları üzerinden dönüștürerek yeniden inşa ettiği söylenebilir. İzleyiciyi ya da okuyucuyu edilgen kılan gazete, dergi, radyo, TV gibi geleneksel medyadan farklı olarak; dijitallilik, etkileşimlilik, hipermetinlilik, modülerlik, erişebilirlik, kullanılırlık, yenilik ve kalıcılık gibi özelliklere sahip olan (Yeniçıktı, 2017, s. 123-126) yeni medya, dinin ve muhafazakâr/dindar bireylerin kamusal alanda görünürlüğünü arttırmıştır. Bu gelişmenin bir sonucu olarak, yeni medyanın muhafazakâr bireyler ve din üzerindeki etkileri tartışılır hale gelmiştir.

Dinler, medyada kendilerine yer bularak mesajlarını geniș kitlelere ulaștırabildikleri ve bu yolla varlıklarını güçlendirebildikleri gibi, medyanın sunduğu kültürel kodlardan ve dayandığı ekonomik mekanizmadan da etkilenmektedir. Özellikle yeni medyanın yaydığı kültürel etki farklı dinsel görünümlerin doğmasına yol açabilmektedir. Bu ikircikli durum, medyanın gerçekliği temelinde sorgulanması gereken daha geniş bir tartışma konusunun kapısını aralamaktadır. Baudrillard (2011, s. 56) simülasyon çağında medyayı, gerçeği hiper gerçeğe dönüştüren bir genetik koda benzeterek, medyadaki gerçekliğin tam olarak çözümlenemez olduğuna vurgu yapmaktadır. Bu yaklaşım çerçevesinde, medyada dine ve dindarlığa ilişkin farklı görünümlerin ortaya çıkmasının altında yatan sebepler, medya ve din gerçekliklerinin çarpışma noktasında aranmalıdır.

Tartışmanın bir diğer ayağı ise tüketim kültürüne dayanmaktadır. Tüketim kültürü ile kültürün bir öğesi olan din arasındaki karşılıklı etkileşim neticesinde meydana gelen değişim, din sosyolojisinde öne çıkan tartışma konularından biri haline gelmiştir. Bu bağlamda araştırmada, tüketim kültürü ve din arasındaki etkileşimin özellikle metalaşma boyutu, yeni medyadaki paylaşımlar aracılığıyla gösterilmeye çalışılarak sosyolojik bağlama oturtulmaya ve tüketim kültürü, medya ve din üzerine yapılan teorik tartışmalar ışığında yeniden okunarak yorumlanmaya çalışılmaktadır. Bu amaçla, dinsel olanın metalaşmasının en fazla göze çarptığı tesettür giyim butikleri, helal belgeli ürünler, dini turizm etkinlikleri ve dini sembollerin ticareti gibi yeni tüketim pratiklerine ilişkin yapmış olduğumuz gözlemlere ve ilgili literatüre dayanarak Türkiye özelinde bir analiz hedeflenmektedir.

\section{Tüketimin Kültürel Boyutu}

Sosyal bilimlerde 1950'li yılların sonlarında Hall, Thompson, Hoggart, Williams gibi Çağdaş Kültürel Çalışmalar Merkezi bünyesinde yer alan düşünürler, kültür çalışmalarına odaklanırlar. Onlar, Gramsci'nin hegemonya çözümlemesini merkeze alarak, alt sınıfların mücadele edebilmek için belirli bir sınıf bilincine erişebilmeleri gerektiğine ve bu bilincin, eğitim ve kültürel yolla sağlanabileceğine dikkat çekerler (Dural, 2012, s. 320). Bu doğrultuda 1950 'lerden itibaren çalışmalar; II. Dünya Savaşı sonrasında yaşanan ekonomik iyileşme ve kapitalizmin gelişimiyle birlikte tüketimde kitlesel artışa ve tüketimin kültürleşmesine yoğunlaşır. Buna göre orta sınıfların tüketime katılması, üst sınıfa ait bir ayrıcalık olan tüketim eylemini geniş bir sınıfsal alana yayar ve tüketim yoluyla çizilen sınıfsal ayrım kriterini de yerle bir eder. Yani artan refah seviyesi ile belirli bir gelire sahip olan bireyler, birer tüketici olarak nitelenirler (Bocock, 2005, s. 31).

Bu durum göstermektedir ki, tüketim kültürünün başlangıç noktası modern toplumdur ve postmodernlik, tüketim kültürünün büyümesini sağlayan arka plan konumundadır (Featherstone, 2013). Özellikle, kitle iletişim araçları ve reklamcılık sektörü gibi uzmanlık alanlarında yaşanan gelişmeler, satın alma gücüne sahip bireyler üzerinde yeni tüketim kalıpları ve deneyimleri ortaya çıkarmıştır. Dolayısıyla, Odabaşı'nın (2017) kültürün eşik tutucuları olarak nitelendirdiği aracı unsurlar, kitlelerin zihinlerini tüketim ile kodlarken, "gösterileni tüket, tükettiğini göster" yönünde bir tüketim anlayışı da şekillendirmektedir. Bu açıdan endüstriyel kapitalizmin gelişimi ile tüketim kültüründe, gösteriş̧̧i boşa harcama ilkesinden tüketim kuralları doğar ve bu durum, tüketiciyi müsriflik standardına taşır (Veblen, 2017, s. 108). Benzer düşünceler, Werner Sombart 
tarafından da dile getirilir. Sombart'a göre, kapitalizm lüksten doğmuştur. Lüks tüketimin kapitalist olan ekonomi biçimlerini geliştirmesinin nedeni, ekonomik kalkınmanın yandaşlarının, aynı zamanda ateşli birer lüks taraftarı olmasından kaynaklanmaktaydı (2013, s. 195).

Öte yandan Bourdieu, kültürel alanı habitus ve kültürel sermaye arasında bağlantı kurarak beğenilerin ayrımı ve faillerin sınıflanmasına aracılık eden bir düzleme oturtur. Bu bakımdan Marx'ın ekonomik sermaye üzerinden temellendirdiği sınıfsal farklılaşma, Bourdieu açısından kültürel sermaye dikkate alınarak, benzer bir ayrıma yol açar. Sınıflar arasında kültürel kalıplar birbirinden farklılık arz ederken, her sınıf, kendi habitusu içerisinde kültürel faaliyetlerini şekillendirdiği için benzer sınıfta olanlar, ortak hayat tarzı ve beğenilere sahip olurlar. Böylece beğeniler, bir sınıfın sistemli ifadesi olarak ayırt edici bir yaşam stilinin temelini oluştururlar (Bourdieu, 2015, s. 261). Habitusun yarattığı kolektif bilinç neticesinde, hâkim sınıf değer yargılarını sürdürmeye çalışırken, alt sınıftakilere de meşru kültürü dayatır ve onların itaate yönelik zihinsel bir mekanizma geliștirmelerini sağlar (Bourdieu ve Wacquant, 2016, s. 31). Bourdieu'ya göre, tüketim de bu noktadan hareket eder. Diğer bir deyişle, bireyin içinde yer aldığı sınıf, kendi konumuna uygun ürünleri tüketmesine ilişkin bir yönelim yaratır. Tüketim, "çeşitli kültürel üretici kategorileri ile çeşitli tüketici kategorileri arasında ayrı mücadele alanlarındaki şahsi mevkilerine göre bilinçli bir uyarlamadan ziyade yapısal türdeşlik ilişkisi kurmaktadır” (Swartz, 2013, s. 191). Ayrım neticesinde tüketim, hâkim sınıflar için Weber'in yaşamın stilizasyonu olarak kavramsallaştırdığı olguya denk düșer ve belirli malların seçimini ya da çeşitli pratikleri yönlendirip düzenleyen sistemli bir bağlılığın ürünü haline gelmeye başlar (Ünal, 2017, s. 384). Böylece bireyin alt sınıfla arasına önemli bir mesafe koyma aracı olur. Bu açıdan tüketimde estetik kaygının ön planda yer alması, üst sınıfa ait bir özelliktir.

George Simmel'e göre de metropol yaşamının yarattığı yabancılaşma karşısında bireyselliği koruma dürtüsü, bireyi tüketim eylemine güdüler (Hürmeriç ve Baban, 2012, s. 93). Simmel modayı, bireysel farklılaşma ve arzulanan değişimi sağlayan bir yaşam formu olarak tanımlar (2013, s. 543). Bu açıdan modanın, modern bireyin kendini var etme çabasının ürünü olduğu söylenebilir. Söz konusu durum, modayı, bir akım olarak ele almanın ötesinde toplumsal kimlik konusuna bağlayarak, ona işlevsellik kazandırır. Simmel'e göre, metropolde nesnel kültürün genişlemesi, bireysel kültürü küçültürken; yaşanan zihinsel dönüşüm içerisinde nitelin yerini nicel unsurlar alır. Simmel'in kültür patolojisi olarak nitelendirdiği bu durum neticesinde, maneviyat, incelik ve idealizm gibi kavramlar gerileme gösterirler (2009, s. 327).

1980'lerden itibaren tüketim kültürü önemli ölçüde değişim yaşamıştır. Ancak bu değişimin bir anda ortaya çıkmadığını belirtmekte fayda vardır. Zira Harvey'in (2010, s. 81) belirttiği gibi, 1970'li yılların başında hegemonik konumunu sağlayan kültürel evrimin, sosyolojik bir arka planı bulunmaktadır. Jameson'a (1994, s. 20) göre bu gelişmeler, kültürü bir meta karakterine büründürürken, bireylerde de zihinsel bir dönüşümü beraberinde getirir. Bu bağlamda tüketim kültürü, dünyanın dört bir yanında benzer tüketim eğilimlerinin sergilenebilmesine olanak sağlayan unsurların birleşimi ile tüketimi amaç haline dönüștüren yeni tüketici modelleri yaratmıştır. 1980 sonrası tüketim kültürünün merkezinde, marka ürünlerin tüketimi bulunur. Markaya olan yönelim, ürünün taşıdığı sembol üzerinden anlamlandırılabilir. Böylelikle tüketim kültürünün temeli, sembol üretimi ile üretilen sembollerin tüketimi arasında devam eden sürekli ilişkiye dayanır ve bireyler arasında tüketim üzerinden gerçekleşen bir rekabeti de körükler. Featherstone’a (2013, s. 159) göre tüketim kültürü dinamiğinin yarattığı sorunlardan biri de kıt ve sınırlı malların piyasaya aktarıldıkça sürekli olarak enflasyona uğraması ve toplumsal yarışa neden olmasıdır. Bu noktada firmalar için temel mesele, marka sadakati yaratarak tüketiciyi tüketim çemberi içerisinde tutabilmektir (Ulaş, 2019, s. 79). 
Sonuç olarak, tüketim toplumunun ortaya koyduğu tüketim kültürü, kapitalist sistemin devamlılı̆̆ının sağlanması amacıyla kitlelere dayatılmış olan bir kültürdür. Böyle bir yapıda kültür merkeze alınarak tüketimin denetlenmesi ve bireyin sistemin içerisinde tutulma politikası esastır. Dolayısıyla duygulara hitap etme ve tüketime dair arzunun sürekli kılınması amacı, reklamcılık ve pazarlama stratejilerini firmaların hayati fonksiyonları haline getirir. Bu noktada ise medya platformlarının gücü yadsınamaz.

\section{Farklı Anlam Dünyaları: Din ve Tüketim Kültürü}

Tüketim, insanın dünya üzerinde ortaya çıktığı andan itibaren gerçekleştirdiği bir eylem iken; tüketim kültürü kavramı, hedonistik bir tüketme eylemine işaret etmektedir. Bu bakımdan din ve tüketim kültürü arasındaki ilişkinin karşıtı̆̆ğ, her iki kavramın gerçekliğe yönelişlerinin birbirlerinden farklı olmasına dayanır. Bu sebeple manevi olanı önceleyen din, merkeze maddi olanı yerleştiren tüketim ve kültürünün aşırılığını, kaçınılması gereken bir davranış biçimi olarak tanımlamaktadır. Öyle ki, evrensel dinlere bakıldığında, Yahudilik'te zevk için israf etmenin yasak olduğu (Tevrat, 20: 19), Hristiyanlık öğretisi içerisinde ise paraya olan düşkünlüğün hoş karşılanmayan bir davranış olarak nitelendirildiği (İncil, 19: 9-10, 26: 8, 12: 2) ve İslam dininin fazla tüketimi tasvip etmediği (Kur'an-ı Kerim, 6: 141, 7: 31, 17: 26-30) yaklaşım ve izleri bu dinlerin kutsal kitaplarında görmek mümkündür. İslam'da israfın, yani arzunun bizatihi kendisi için yapılan tüketimin, "haddi aşma, gaflet” olarak tanımlanması (Kallek, 2001), hayatı kul olarak değil de nesnelerle anlamlandırmaya çalışmak sonucunu yaratmasından dolayı, din ve tüketim kültürü arasında bir gerilimin varlığına işaret etmektedir. Zira dindar insanlar bir yandan kendilerini kulluk üzerinden tanımlamaya çalışıllarken, diğer yandan bilinçli veya bilinçsiz olarak markaların işaret değerlerini satın almak için yarışmaktadırlar (Demirezen, 2010, s. 106).

Din ve tüketim arasındaki ilişkinin sosyolojik boyutlarını anlamlandırmada Weber'in din yaklaşımı ayrı bir önem taşımaktadır. Weber, kapitalizmin ruhunu oluşturan şeyin üretmekten geçtiğini ifade ederken, gereksiz harcama ilkesinden uzak kalma ve israf etmeden biriktirme öğretisinin kapitalizmin gelişiminde yarattığı etkiye değinir. Paranın lüzumsuz tüketimi sermaye kaybına yol açacağı için akıldışılık kabul edilmektedir (Weber, 2014, s. 53). Nitekim Kalvinizm öğretisi, Tanrı'nın bağışlamasına ulaşabilmek için daha çok çalışmak, biriktirmek, başarıı ılmak gibi temel prensiplere dayanır. Weber (2016, s. 353) bu nedenle Protestanlığın bu dünyacı asketizminin kapitalist bir ahlak üretimine yaptığı katkıya vurgu yapar. Zaman içerisinde kapitalizmin yaygınlaşması ekonomik mantığı genişletirken, bireyin gündelik hayatında dini ve ahlaki öğretilere dayanan referanslarını daraltmıştır. Yani kapitalizmin, dinin manevi desteğine ihtiyacı kalmamıştır (Ülgener, 1981, s. 260). Bu sonuç, tüketim toplumunda kapitalizmin bütün dinleri etkileyen bir güce ulaştığı ve tüketim kültürünün de dinsel olanın içine yerleştiğini göstermektedir. Kapitalizmin desteklediği tüketim ideolojisinin, geleneksel kültür kodlarını küresel değerlere entegre etmeyi hedeflemesi, Müslüman toplumlarda da kültürel dönüşümlere sebebiyet vermekte ve sonuçta küreselleşme ve neoliberalizm ile eklemlenmenin yeni dinsellikler geliştirdiği görülmektedir (Haenni, 2014, s. 21). Bu durum, dinin çeşitli hassasiyetler üzerinden yeniden anlamlandırıldığı ve tüketim kültürünün temelleriyle bağlantılı yeni bir dindar kimliği açığa çıkartmaktadır (Göle, 2017, s. 21). Sonuçta, hedonistik tüketim, dinin yaşam içerisindeki belirleyici konumunu geri plana iten tutum ve düşüncelerin gelişimine yol açar; yani din ve dindarlığı sınırları kaybolmuş bir alana taşır.

Din ve tüketim arasındaki ilişkiyi giriftleştiren bir diğer önemli nokta ise, dini algıyı şekillendiren araçlardaki değişimlerdir. Kısacası, medya kültürü, dini kültürü zamanın ruhuna uyarlayarak, onu yeniden tanımlar. Dolayısıyla dinin medyada yer alması, kaidelere uymak zorunluğunu ortadan kaldırdığı i çin bambaşka bir sorun oluşturur (Postman, 2017, s. 112). Son tahlilde, herkesin tüketici konumuna geçtiği bir ortamda pazar mantığının devreye girmesi, dini olan her şeyin ticari bir nesneye dönüşmesine yol açar ve bu durum, aynı zamanda dini otoritenin giderek silikleștiği medyada (Dereli, 2020, s. 294), geleneksel anlamların da önemsiz hale gelip tüketilmesine neden olur. 


\section{Medyada Din ve Tüketim Ilișsisinin Serüveni}

Medyada din ve tüketim ilişkisinin ilk örneklerine, kutsal kitaplar ve dini eserlerin tüketiminde rastlanmaktadır. Zira 15. yy.'da Gutenberg matbaayı icat ettiğinde, ilk reklamların çoğu İncil satışı içindi. Genel kanının aksine, tarih boyunca din adamları matbaadan uzak kalmamış ve vaazlarını kitlelere ulaştırabilmek amacıyla dua kitapları hazırlamışlardır (Einstein, 2007). Tarihsel süreç içerisinde dini pazarın ilk girişimlerinin özellikle Amerika'da görülmesinin ve yaygınlaşmasının sebebi, ABD'deki din özgürlüğüne ilişkin ilk yasal değişikliktir. Dini grup ve topluluklarda bir çeşitliliğin söz konusu olması ile her kolonide farklı kilise-devlet ilişkisi modelleri uygulanmıştır (İmga, 2010, s. 22). Bu durum, kendilerine üye çekerek pazar payını arttırmak isteyen kiliselerin, dini pazarlama ve reklam tekniklerinden yararlanmasına yol açmıştır (Kirman, 2005, s. 153).

Erken dönemde Batı'da, tüketmenin ülkenin kalkınması için fedakârlık olduğu yönünde bir bilincin yerleşmesi ile insanların kiliseye gitmek yerine dini bilgiyi yazılı kaynaklardan öğrenmesi ya da inançlarını temsil eden sembolleri satın almaSI gibi bir dizi pratik gelişmiştir. 1990'larda, radyo ve televizyonlardaki sohbetler dışında, din ve tüketim ilişkisinin daha çok basılı yayında yoğunlaştığı söylenebilir (Einstein, 2007, s. 40). 2000'li yıllarda ise dini filmlerin Hollywood'da gişe rekorları kırması ve müzik dünyasında çağdaş Hristiyan müziğinin yükselişe geçmesi, dini pazarın cazibesini arttıran iki önemli gelişme olarak görülmektedir. Bu durum, filmlerdeki dini sembol ve karakterlerin ürün olarak satışa sunulması ve Disney, McDonald's, Pepsi gibi birçok ünlü firmanın ürünlerini tanıtmak amacıyla dini müziğin temsilcilerini kullanması şeklinde karşılık bulmuştur (Seybert, 2004, s. 24).

Öte yandan, Müslüman toplumların kitle iletişim araçlarında yaşanan gelişmelerden azade olmayarak, medyada sunulan batılı yaşam tarzını örnek aldıkları ve zihinlerinde "batılı gibi tüketme" anlayışının yerleşmeye başladığı söylenebilir. 1990'lardan itibaren İslami müzik ve giyim tarzı bașta olmak üzere kültürel alanda dikkati çeken dönüşümler yaşanmıştır (Haenni, 2014, s. 54). Geleneksel dini enstrümanlar ve ezgilerin dışına çıkılarak, dini kavramların kültürel fragmanlar olarak yer aldığı yeşil pop ve İslami-rap müziğin yükselişe geçişi, bu duruma örnek teşkil etmektedir (Dursun, 2016, s. 211). Bu dönüşüm, benzer biçimde sinemada da etkisini hissettirmiştir. İslami filmlerdeki üslubun, modern ve geleneksel olanın iç içeliğiyle karakterize edilişinin nedeni, geleneksel ve modern yaşam tarzı arasında oluşturulmaya çalışılan anlatısal arayıştan da kaynaklanmaktadır (Özdemir, 2011, s. 28). Günümüz İslami gençlik filmlerinde, romantizme ve tek başına karar veren özgür kadın imajına ağırlık verildiği dikkat çekmektedir. Örneğin, birçok dile çevrilmiş ve ödül kazanmış olan Endonezya yapımı Selamünaleyküm Pekin (Assalamualaikum Beijing, 2014) adlı filmde kendine yetebilen genç bir kızın hayatı konu edinilmektedir. Bu filmin, din, tüketim ve medya ilişkisindeki önemi ise daha sonra çizgi romana uyarlanarak piyasaya sürülmesi ve böylece, filmi izlemeyen kesimin de tüketimin içerisine çekilmeye çalışılmasıdır. Filmin çizgi roman uyarlaması, Müslümanların yaşam tarzlarındaki değişimi örneklemektedir. Bu durum, dini değerlerin seküler ürünlere dönüştürülerek, gençlerin popüler kültürdeki ihtiyaçlarının karşılanmaya çalışıldığı şeklinde yorumlanmaktadır (Adji, 2019, s. 169).

Türkiye'de ise 1950 'lerden 2000 'li yıllara gelinceye kadar, modernleșme ve batılı yaşam tarzının ön plana çıkartıldığı reklamların ağırlıkta olduğu söylenebilir. Bu bağlamda, Althusser'in (2017, s. 61) ideolojik aygıt olarak tanımladığı haberleşme araçlarında, gelenekselcilik ve muhafazakarlığın tasvip edilmediği ya da olumsuz anlamda tasvir edildiği reklamların varlığından bahsedilebilir. Özellikle 1950 ve 1970 arasındaki reklamlarda, dindarlık ya da genel olarak muhafazakarlığın modernliğin karşısında konumlandırıldığı ve "modern birey tüketmelidir" mottosunun izleyicilere aktarıldığı dikkati çekmektedir. Zira Sümerbank reklamında, şehirli kadının mutlu bir biçimde, başörtülü köylü kadının önünde resmedilmesi ${ }^{2}$ ya da $\mathrm{Ay}$ gaz reklamında, "Tezekle odunu defettik. Aygaz aldık rahat ettik" gibi sloganlar 
ile modernleşme söylemleri pekiştirilmiştir. 1980'lerden itibaren yaşanan ekonomik, kültürel ve siyasal dönüşümlerin muhafazakâr kesim üzerinde yarattığı etki, görsel ve yazılı basının içeriğine yansımış ve dergilerde lüks malların tanıtıldığı reklamlar giderek artmıştır. Tüketim kültürünün giderek benimsenmesine paralel olarak dergi ve reklamlarda yaşam tarzı oluşturmaya yönelik içerikler geliştirilmiştir.

Kısacası gelinen noktada, nasıl giyinilmeli, nereden alışveriş yapılmalı gibi imaja yönelik sorulara cevap bulabilme arayışının giderek artması, tüketim kültürünün insanlar üzerinde yarattığı etki olarak izah edilebilir. Öte yandan medya, piyasa içerisinde yer alan birçok ürünün reklam kampanyasını dinsel değerleri göz önüne alarak yeniden düzenlenmektedir. Bu durum, bir yandan sistemin desteklediği ideolojinin pekiştirilerek tüketim kültürünün genişlemesine neden olurken; diğer taraftan dini değerlerin metalaşma sürecine ivme kazandırmaktadır. Son tahlilde medyanın dini değerleri dönüştürücü etkisi, dindar bireyin gündelik yaşam pratikleri ve zihinlerinde de önemli dönüşümlere sebebiyet verebilmektedir.

\section{Yeni Medyada Din ve Tüketim}

Yeni medya, tüketimin önündeki her türlü engeli ortadan kaldırarak, bireye teknolojik araçlarla (sosyal medya, mobil uygulamalar, web siteleri) istediği şeyi istediği yerde tüketme imkânı sağlayabilmektedir (Ritzer, 2016). Ayrıca bu ortamlarda her şeyin ticaretinin yapılabilmesine uygun koşullar girişimcilere sunulmaktadır. Bu doğrultuda, yeni medyada dini ürünler yanında, özünde dini olmayan ürünlerin de dini bir formatta satışa çıkarıldığı görülmektedir. Böylece kapitalist sistem yeni medyadaki işleyişiyle, hem hazcı ve gösteriş̧̧i tüketimi yayarak dinin tüketim ahlakıyla çatışmasına hem de kutsalın tüketim nesnesine indirgenmesine yol açmaktadır.

Bu bağlamda online dini alışveriş siteleri, inançlı bireyler tarafından ilgi görmektedir. Illk defa, geniş ürün yelpazesine sahip olan İslami alışveriş sitesi, 2013 yılında Hamburglu bir öğrenci olan Selim Reid tarafından kurulmuştur. Selisha.de adlı sitenin giriş sayfasında yer alan "islami Yaşam Tarzı Kolaylaştı" sloganı, aynı zamanda Selim Reid'in siteyi kurma amacını da ifade etmektedir. Ona göre, yurtdışında yaşayan Müslümanların alışveriş yapabilecekleri site sayısının az ve satın alabilecekleri ürünlerin kısıtlı olması, sitenin kuruluş amacını oluşturmaktadır (Timetürk, 2013). Online alışveriş sitelerinde satın alma işlemi, üye olarak veya üye olmadan gerçekleştirilmektedir. Alışveriş sitelerinde hac malzemeleri, dini hediyelik ürünler, mevlit setleri, dini eserler, seccade, dini eğitim setleri, aksesuarlar, esans ve kokular, zemzem takımları ve rahleler, hurma tasları, umre sandaletleri, tesettür mayosu, namaz elbisesi, başörtüsü, korunma duası içeren muskalar, tesbih, zikirmatik gibi ürünler yer almakta olup tüketicilere kredi kartı, kapıda ödeme ya da banka havalesi ile ödeme seçenekleri de sunulmaktadır. Online alışveriş sitelerinde İslam ile tüketilen ürünün örtüşüp örtüşmediği ise çoğunlukla "helal" kavramı üzerinden değerlendirilmektedir. Sitelerde din adamlarının konuya ilişkin bilgilerine yer verilerek dindar bireyin kaygıları giderilmektedir. ${ }^{4}$ Dolayısıyla, "helal" ibaresi ile tüketimdeki dini sınırlar vurgulanarak belirtilmektedir. Ancak bu sitelerde, satılan ürünlerin sadece dini içerikli ürünler olmadığı, aynı zamanda modern kültür öğelerine de yer verildiği görülmektedir. Mesela, Muslimwalk sitesinde, bir yandan her kesime hitap eden ürünler yer alırken, diğer taraftan tesettürlü kız figürleri bulunan kitap ayraçları, Zümer Suresi 36. ayetin yer aldığı tablo ya da Ramazan ajandaları gibi içeriğinde dini sembollerin olduğu ürünler de satılmaktadır. ${ }^{5}$

Yeni medyada din ve tüketimin melez yapısı, hem firmaların müşteri kitlesini genişleterek kazançlarını arttırma isteğinin hem de hedef kitlenin modern eğilimlerinin bir neticesi olarak okunabilir. Zira Göle'nin (2017, s. 16) ifade ettiği üzere melezleşme, yeni İslami yüzlerin kendi cemaatlerinin dışına çıkarak bireyselleşmeleri ve farklı kesimlerle geliștirilen diyaloglar sonucunda, geleneksel saflığın kaybedilmesinden kaynaklanmaktadır. Nihayetinde insanların çevrimiçi kimlikleri ile fiziki ortamdaki kimlikleri arasında büyük ayrımlar bulunmamaktadır (Dereli, 2019, s. 108). Bu sebeple, yani fiziki ortamdaki yaşam tarzları ile çevrimiçi ortamlardaki davranışların örtüşmesiyle, internetin önerdiği yaşam kalıpları kabul edilmektedir (Saydan ve Nart, 2019, s. 91). 
Dindar bireylerin değişen ve dönüşen taleplerinin Türkiye'de de firmalar tarafından dikkate alındığı ve firmaların ürünlerini bu yönde tasarlandığı görülmektedir. Bu anlamda, üreticilerin dijital ortamlardaki faaliyet alanlarının oldukça çeşitli olduğu görülse de din ve tüketim ilişkisinin özellikle tesettür giyimi, helal içerikli ürünlerin pazarlanması, İslami turizm ve organizasyon şirketleri ile dini sembollerin ve ürünlerin tüketimi olmak üzere 4 temel kategoride ön plana çıktığı söylenebilir (Gazneli, 2020).

\subsection{Tesettür Giyim Butikleri}

Günümüzde, yeni medyada din ve tüketim ilişkisinin en fazla görüldüğü alanın tesettür giyim sektörü olduğu söylenebilir (lacivertdergi, 2015). 1980’lerden sonra, modanın tesettürlü kadınların giyim tercihlerinde rol oynaması, tesettür giyim perakendecilerinin de dikkatini çekmiş ve pazar paylarını arttırmak amacıyla farklı pazarlama stratejileri uygulamaya başlamışlardır (Eren ve Atılgan, 2019, s. 44). Bu anlamda Tekbir Giyim, Modanisa, Modamerve, trendtesettür.com, e-tesettür.com, Sefamerve gibi daha birçok firmanın satışlarını arttırmak amacıyla yeni medyadan yararlandıkları görülmektedir. Tesettür firmalarının web sitelerine bakıldığında dış giyim, başörtüsü, büyük beden, spor/deniz, ayakkabı/aksesuar, abiye gibi kategoriler yer almaktadır. Yeni medyada ürünlerin sınıflandırıması, tüketicinin aradığını kısa sürede, zorlanmadan bulabilmesiyle bir avantaj sağlamaktadır. Nitekim akılcılaştırmanın bir ürünü olan kataloglaştırma yöntemi, Ritzer'in (2016, s. 133) ifade ettiği üzere, bireyin modern yaşamın meşguliyeti karşısında verimliliğini arttırmaktadır. Öte yandan, sistemin temel amacı, bireyleri gelirlerine göre ayrıştırarak, uygun tüketim kalıplarını geliştirmektir. Bu anlamda, kapitalist sistemdeki genişleme, beraberinde refah ve zenginleşme gibi olguları getirmediği gibi; aksine işlevsel düzey farklılığını ve bu dengesizliği rasyonelleştirerek ve tüm düzeylere yayarak doruk noktasına ulaştırır (Baudrillard, 2018, s. 57). Bu doğrultuda, tüketim toplumunda eşitsizliğin gözükmeyen ve derinden işleyen yapısının yeni medyada yeniden üretildiği söylenebilir. Zira dijital ortamlardaki alışveriş sitelerinin genel yapısı, Adorno'nun (2013, s. 51) yaklaşımıyla değerlendirildiğinde, tüketicileri değişik gelir gruplarına göre ayırarak birer istatistik malzemesine dönüştürmekten başka bir şey değildir. Nihayetinde yeni medyada tüketimin sınıfsal karakteri, sayfaların girişinde indirimli ürünler ve yeni koleksiyonlar gibi ayrımlar ile görülmekte olup birey, bu ortamlarda bir standartlaşmanın içerisinde yer almaktadır.

Son yıllarda Instagram kullanıcı sayısının artışı, tesettür firmalarını sosyal medyada ürün satışına yöneltmektedir. Dijital ortamlarda butiklerin takipçi sayılarının fazla olması, tüketiciler açısından güven ifade etmektedir. Bu durum, üretici kesimin doğru hashtagler seçerek takipçi sayılarını arttırmasına ve paylaşımlarının daha fazla kişiye ulaşmasını sağlayacak stratejilere başvurmasına neden olmaktadır (Onurlubaş ve Öztürk, 2018, s. 991). Bu stratejilerden biri, muhafazakâr fenomenler aracılığıyla ürünleri tanıtmaktır. Sosyal medya ünlüleri, influencer ya da dijital fikir önderleri ${ }^{6}$ gibi kavramlar ile literatürde yer bulan fenomenler, bir nevi toplum tarafından kabul gören kanaat önderleri olarak tanımlanabilir (Alikılıç ve Özkan, 2018, s. 48). Bu sebeple, fenomenler tarafından tavsiye edilen ürünler, kullanıcıların gözünde "makbul ürün” niteliği taşımaktadır. Diğer bir deyişle, muhafazakâr fenomenlerin tüketim alışkanlıkları, onları takip eden kişiler tarafından dikkate alınmaktadır ve takipçiler, fenomenlerin kullandıkları ürünleri satın alma yönünde eğilim göstermektedirler (Gazneli, 2020). Bu anlamda, görsel olarak yoğun reklam ve pazarlama taktikleri, sadece tüketimin gerçekleşmesini sağlamamakta, aynı zamanda bir yaşam tarzının üretilmesine de yol açmaktadır. Baş örtmekte kullanılan örtünün adı yerleşik kullanımda "başörtüsü" ya da "eşarp” iken, son yıllardaki sosyal medya paylaşımlarında "şal” kelimesinin kullanılmaya başlandığı gözlemlenmektedir. Zira örtünmenin tesettür amacıyla kullanılmayan bir giyim ögesiyle ifade edilmesi, dinden ziyade modaya referans veren bir sözcük tercihi olarak da okunabilir. Nitekim sosyal medyanın, dindar genç kızların kıyafet tarzlarına ve hatta 
hayatlarının diğer alanlarına doğrudan etki ettiği ve onların dini kimlik perspektiflerini önemli ölçüde değiştirdiği niteliksel araştırma verilerinde de görülmektedir (Bkz. Dereli, 2020, s. 184).

Giddens'ın (2014, s. 110) modern toplumdaki muhtemel seçimler çokluğunun bir ifadesi olarak ele aldığı yaşam tarzı, geleneksel ve dini kültürde fazla uygulanabilirliğe sahip bir kavram olmadığı gibi gelenekseli parçalayarak yerine yenisini koymayı hedefler. Dolayısıyla tesettür firmaları, bir yandan ürünün satışına yönelik tanıtımlar yapar ve tüketimi sağlar iken; diğer taraftan eşarbın/şalın nasıl bağlanması gerektiği, hangi renklerin bir arada kullanılmasının doğru olduğu, hangi pantolon ile hangi kazağın kombin edilmesi gerektiğine ilişkin öneriler vererek, modern Müslüman kadın imajının ve kimliğinin üretilmesi sürecine katkıda bulunmaktadır.?

Günümüzde din ve tüketim ilişkisinin tesettür bağlamında görünen bir başka boyutu ise, tesettürün lüks tüketim içerisine dahil olarak statü göstergesi haline gelmesidir. Bu doğrultuda, sosyal medyada gerek firmaların gerekse kullanıcıların giyimde İslami kaidelerin ötesinde markayı ön plana çıkarması, tesettürün tüketim nesnesine dönüşmesi sürecini hızlandırabilmektedir. Featherstone (2013, s. 159) tüketim kültürü dinamiğini rekabete dayandıııken, bu yarıșın sembolik anlamlar üzerinden yürütüldüğünü dile getirmektedir. Böylece, tesettürde markalaşmak ya da markaya yönelim, bireyin diğerlerinden farklı olmasını sağlayan bir araç olarak karşımıza çıkar. Bourdieu (2015, s. 95) ise tüketimden bahsederken, nesneyle kurulan ilişkinin sınıfsal beğeni yargilarına göre temellendiğini ifade eder. Bu perspektifler çerçevesinde, tesettürde ortaya çıkan beğenilerin sınıf farkını ve ayrımını yansıtan kültürel standartlar haline geldiği söylenebilir. Öte yandan Veblen'in (1899) sınıf tipolojisinde ifade ettiği üzere alt sınıfın tüketime yönelik referansının üst sınıflar olması, firmaların pazara imitasyon (taklit) ürünler sürerek alt kesimi de tüketime çekmeye çalıştığı bir dizi pratiğin gelişmesine yol açmaktadır. Son tahlilde, bireyin başörtüsünde önceliği sembolik değere vermesinden kaynaklı ayrışmanın giderek artması ve alt sınıftakilerin üst sınıfların zevk ve beğenilerini taklit etmek istemelerinin de bir sonucu olarak, firmalar lüks ve orijinal marka ürünlerin yanı sıra bu ürünlerin taklitlerini de internette daha uygun bir fiyata satışa sunmaktadır.

\subsection{Helal Belgeli Ürünler}

Kapitalizm, çarkını döndürebilmek için sürekli yeni tüketim alanları açan mekanizması gereği, dini hassasiyeti olan kitleler için de helal belgeli ürün piyasasını yaratmaktadır. Dolayısıyla bu durum yeni medyada, din ve tüketim ilişkisinin helal olgusu üzerine temellendirildiği yeni iş kollarını ortaya çıkartmaktadır. Helal belgeli ürünlere ve bu sertifikasyon sistemine yönelime sebep olan unsurların başında, batıdan ithal ürünlerin içeriğine duyulan kaygıyı giderme ihtiyacı gelmektedir (Çukadar, 2017, s. 191). Türkiye'de helal sertifikası, Gimdes (Gıda ve ihtiyaç Maddeleri Denetleme ve Sertifikalandırma Derneği) başta olmak üzere TSE, Dünya Helal Birliği, Helalder ve Hedem tarafından verilmektedir. Herhangi bir firmanın bu sertifikayı alabilmesi için ürünün imal edildiği yerden kullanılan malzemelere kadar geniş bir denetlemeden geçmesi gerekmektedir. Dini hassasiyeti yüksek olan ve helal ürünleri tercih eden kişileri bilgilendirme ise resmî web siteleri üzerinden sağlanmaktadır. Sitelerde helal ürünler, niteliğine göre kategorilere ayrılmış olup sertifikası iptal edilenler, süresi geçenler, yenilenenler ve askıya alınanlarla ilgili de tüketiciler aydınlatılmaktadır.

Buna göre helal sertifikalı ürünlerin, İslami açıdan câiz olması kuralına ek olarak "tayyip" (temiz) olma kurallarına da uyması koşulu konulmaktadır. Bu doğrultuda tayyip ürün; çevreye duyarlı, mümkün olduğu kadar organik, sağlıklı ürünler ile daha ahlaki bir üretim sürecini ifade etmektedir (Janmohamed, 2018, s. 346). Yeni medyada helal tüketim üzerine birçok site bulunmakta olup dikkati çeken iki satış sitesinden biri, 2012 yılında sektöre giren ve "Türkiye'nin en büyük helal gıda mağazası" sloganı ile satış yapan Onlinehelal.com sitesidir. Bir diğeri ise kırkın üzerinde şubesi ile hizmet veren Halal Dünya Marketleri adlı sitedir. Sitelerin içerisinde gıda dışında kozmetik ve kişisel bakım ürünleri, temizlik ürünleri, naturel ürünler, hac ve umre ile mevlid hediyelikleri 
de satılmaktadır. Web sitelerinin ana sayfaları incelendiğinde, bütün ürünlerin \%100 helal sertifikalı, sağlığa ve dine zararlı olmayan ürünler olarak tüketicilere sunulduğu görülmektedir. Bu yönde, Müslüman toplumlarda bilinçli tüketim anlayışının da giderek benimsenmesi, firmaların maddi ve manevi kaygıları giderme amacı taşıyan gerekçeler göstermelerine yol açmaktadır. Zira, Gumbri ve Noor (2016) tarafından yapılan bir araştırmada da helal sertifikalı ürünlerin tüketimi ile bilinçli tüketim arasında doğrusal bir ilișki olduğuna rastlanmaktadır. Bu bağlamda, Gimdes onayı ve alışveriş karşılığında Dünya Helal Vakfı'na destek olunacağı yönündeki ibareler, bu vesileyle iyilik yapıldığına ve İslami koşulların yerine getirildiğine dair manevi tatmin; ücretsiz kargo, avantajlı ve güvenli alışveriş seçenekleri ise maddi tatmin sağlamaya yönelik olarak müşterilere sunulmaktadır.

Öte yandan, Facebook paylaşım sitesinde de Helal Sertifikalı Gıdalar Destek Platformu, Gimdes Helal Gıda Gençlik Halkası, Doğal ve Helal Ürünler adlı takipçi sayısı yüksek olan sayfalar yer almaktadır. Bu sayfalar aracılığıyla dindar bireylerin helal olgusu üzerinden bir topluluk meydana getirdikleri söylenebilir. Zira online topluluklar, insanların ortak ilgileri çerçevesinde bir araya gelerek birbirlerini destekledikleri, bütünleştirici bir kimlik tasavvuru inşa eden topluluklardır (Şahin, 2013, s. 68). Ancak helal topluluklarındaki aidiyet tasavvuru sadece dini bağlamda kalmamakta; aynı zamanda, sağlıklı yaşama da yönelik olmaktadır ki bu nokta, "helal" kavramının nasıl bir anlamsal dönüşüme uğradığını göstermesi açısından dikkate değerdir. Bu doğrultuda, Hasmin ve Musa (2014) ile Mohezar ve arkadaşlarının (2016) yapmış olduğu çalışmalar, helal ürünleri tercih etme nedenleri ile sağlık arasındaki güçlü ilişkiyi göstermektedir. Öte yandan, Sülün'ün (2014) çalışmasında da bazı tüketicilerin helal ürünlere yönelmesindeki temel sebebin dini değil, temizlik gibi sağlıkla ilişkilendirilecek temellere dayandığı fark edilmektedir. Son tahlilde, helal ürünleri satın alan ya da bu topluluklara üye olanların sadece dindarlar değil; sağlıklı bir yaşam sürmek isteyenler de olması, helal kavramını dini anlamının ötesine taşımaktadır.

Organik belge ile tasdiklenen sağlığa zararsız olma koşulunun dini bir kavramla belgelendirilmesi yeni bir tüketim alanını yaratmaktadır (Bkz. Mohezar vd., 2016). Diğer taraftan, helal kapsamının tüketim boyutuyla genişlerken içerik olarak daraltılması, helal kavramının içinin boşaltılarak tüketilmesi ve metalaşması sonucunu doğurmaktadır (Sofuoğlu Kılıç ve Gazneli, 2020, s. 364). Böylece, alkolsüz malt içecekler, sure isimlerinin verildiği alkolsüz şaraplar, ${ }^{8}$ şampanyalar gibi birçok ürünün helal kapsamına sokulup dindar tüketiciler hedef alınarak üretilmesi gibi örneklerle karşılaşmak; tüketim kültürünün, dini kültürün önüne geçmesi ve tüketimin dinen meşru bir zemine oturtulması şeklinde okunabilir.

\section{3. İslami Turizm ve Organizasyon Şirketleri}

Müslüman ülkelerdeki refah seviyesinin artması ve tüketim kültürünün yaygınlaşmasının etkisiyle, dini hassasiyeti yüksek olan bireylerin seyahat, dinlenme, eğlenme arzularını karşılamak üzere helal olarak nitelendirilen turizm ve organizasyon şirketleri küresel pazarda yerini almıştır (Yıldız ve Yıldız, 2018, s. 774). "The State of the Global Islamic Economy Report 2016/17" araştırmasına göre Müslümanların harcamalarının, 2015 yılında yaklaşık 1.9 trilyon ve İslami finans sektörünün ise yaklaşık \$2 trilyon olduğu belirtilmiştir. Yine 2015 yılında, Müslümanların yiyecek ve içecek harcamalarının \$1.17 trilyon, giyim harcamalarının \$243 milyar, medya ve rekreasyon için \$189 milyar, seyahat için \$151 milyar, kozmetik ürünleri için \$133 milyar harcadıklarına yer verilmiştir. Aynı araştırmada 2021 yılında İslami finans sektörünün \$3.5 trilyona ulaşacağına dair tahminlerin yanı sıra Müslümanların helal yiyecek ve içeceğe \$1.9 trilyon, helal seyahat için \$243 milyar, giyim için \$368 milyar, helal medya ve rekreasyon için \$262 milyar, kozmetik ürünleri için \$213 milyar harcayacaklarına dair öngörülere yer verilmektedir (Yıldız ve Yıldız, 2018, s. 775).

Bu ürün ve hizmetlerin tanıtımı ve reklamı için firmalar yine, yeni medyayı çok etkin olarak kullanmaktadır. Yeni medyada hac ve umre turizmi faaliyetini üst- 
lenen firmalar bu mecralarda hem kendi kanalları üzerinden hem de sosyal medya fenomenlerine reklamlarını yaptırmak suretiyle; paket programlar, kişiye özel umre seyahatleri, kredi kartına taksit imkanları gibi seçenekler ile tüketimi kişiselleştirmektedir. Firmaların düzenlediği kişiye özel tur programlarının fiyatı, normal programlara göre yüksek olup üst sınıf tüketici kitlesine hitap etmesi yönüyle, gösteriş̧̧i tüketimin konusu haline gelmektedir. Bu doğrultuda, sosyal medya platformlarında hac ve umre organizasyonu sayfalarında, reklamı yapılan programların içeriğindeki sınıfsal ayrım dikkati çekmektedir. Hac ve umre programları, Deluxe, Classic ve Butik olmak üzere üçe ayrılmaktadır. ${ }^{9}$ Programlar arasındaki fark, hacı adaylarına sunulan özel otobüs gezileri ve üç öğün sınırsız açık büfe gibi ekstra hizmetlerden kaynaklanmaktadır. Pişkin'in (2016) araştırması da tamamen ticari mantığın ön plana çıkartıldığı ve tüketimi destekleyen organizasyonlarda, hac ve umre ziyaretlerinin birey için konforlu bir tatile çevrilerek, dini anlam ve değerlere yönelik tüketimin hedeflendiğini göstermektedir. Bu araştırmanın katılımcıları, bu konforlu hac ve umre ibadeti sırasında hem her türlü konforu talep etmekte hem de diğer taraftan bu lüks pratiklerin, söz konusu ibadetlerin manasıyla uyumsuz olduğunu da kabul etmektedirler. Böylece hac ve umre seyahatleri turistik birer geziye dönüşmekte, dini mekânların manevi anlamını istismar etmekte ve bireylerin dine yabancılaşmasına neden olmaktadır (Koç, 2019, s. 157). Nitekim Diyanet İşleri Başkanlığı 2002 yılında bu konuya ilişkin yayınladığı raporda, hac ve umre ziyaretlerinin ibadet niteliğini kaybederek inanç turizmine dönüşmesinden ve metalaşmadan bir tehlike olarak bahsetmektedir (DiB, 2002).

Veblen'e (2017, s. 79) göre modern toplumda sınıfsal farklılaşmayı ve saygınlığı sağlayan kıstas, gösterișe dayanan lüks ürün ve hizmetlerin tüketimi olmaktadır. Dolayısıyla, modern toplumda cemaatteki saygınlık, maddi güce dayanır ve bu gücü sergilemenin yolu, gösterişçi tüketimden geçer. Yani, tüketiciler için ürüne ya da hizmete sahip olmak, aynı zamanda bireyin toplumsal kimliğinin tanımlanması ve sınıflandırımasında önemli bir araç haline gelir. Tüketim toplumunda hâkim olan bu paradigma, İslami olarak nitelendirilen turizm şirketlerinin de program içeriklerini etkilemektedir ve kutsal değerler, tüketim sürecine prestij ve saygınlık kazandırma amaçlı dahil olmaktadır. Baltacı (2019) da muhafazakâr tüketimi ele aldığı çalışmasında, tüketimin din eksenli dönüşümüne dair benzer tespitlerde bulunmaktadır.

Din ve turizm ilişkisinin, tüketim açısından değerlendirilebilecek diğer boyutu ise tatil anlayışıdır. Özellikle son yıllarda, beş yıldızlı İslami oteller ile belirli süreler için kiralanan ultra lüks tatil evlerinin ve turların sosyal medyada reklamları artmış, firmalar tarafından sunulan lüks tatil konsepti giderek muhafazakâr bireyler tarafından tercih edilmeye başlanmıştır. Türkiye'de helal turizm işletmeleri ile ilgili herhangi bir resmi istatistik bulunmamakla birlikte, Türkiye'deki helal konseptli oteller üzerine yapılan araștırmalar, Türkiye'de 2002 yılında sadece 5 helal konseptli hizmet ve ürün sunan otel varken, 2015 yılında sayılarının 207'ye ulaştığını göstermektedir. Buna göre ülkemizdeki helal konseptli otellerin 25'i Akdeniz bölgesinde, 17'si Doğu Anadolu bölgesinde, 50'si Ege bölgesinde, 13'ü Güneydoğu Anadolu bölgesinde, 25’i iç Anadolu bölgesinde, 27'si Karadeniz bölgesinde ve 50'si Marmara bölgesinde yer almaktadır (Yıldız ve Yıldız, 2018, s. 778). Tesettür, Helal ya da íslami gibi çeşitli isimlerle tanımlanan otel ve turların internet sayfalarında, gelen konuklara bir yandan dini kurallar çerçevesinde hizmetler sağlandığı vurgulanmakta; diğer taraftan erken rezervasyon fırsatı ile ekstra geziler gibi bütçelerine uygun, keyifli vakit geçirebilecekleri imkanlar sunulmaktadır. Böylelikle, din ve boş zaman arasında kurulan dengede, esnekleşmiş ve bireyselleşmiş ihtiyaçlara yönelik arzunun canlı tutulduğu görülmektedir. Sosyal medyadaki reklamlar ise arzuların sürekli yeniden işlemden geçirilmesi ve firmaların ticari manipülasyonu ile merkezi bir önem kazanır (Featherstone, 2013, s. 125). Dini içerikli turizmde görülen melezleşme ile dinin, toplumsal faaliyetin arta kalan kısmından ayrık bir nesne gibi konumlandığı söylenebilir. Turlarda, "yalnızca muhafazakâr aile ve çiftlere yer verilmesi"10 gibi kimliğe yapılan vurgular ise Weber'in inanç ve etnik temelli kapanma modelinin arka planını oluşturan ekonomik stratejiler bağlamında değerlendirilmelidir (Özet, 2019). Nitekim tatil firmalarının sayısındaki artışa paralel olarak artan rekabet ile "is- 
lami Konsept”, “Muhafazakâr Tur”, “islami Tatil” söylemlerini ön plana çıkartan firmaların muhafazakâr kesime yönelmesi, diğer firmalar karşısında kârını arttırmasına sebep olmaktadır. Bauman'ın (2017, s. 121) ifade ettiği gibi, tüketim toplumunda tüketici talebi ile arz arasındaki dengeyi korumak için çift yönlü bir uyarana ihtiyaç vardır ki bu ihtiyaç, arzu etmekten geçer. Bu anlamda, muhafazakâr kesim tarafından helal tatil evlerine yönelik talebin artmasındaki sebep, bireye sunulan konfor kadar, arzu edilen mahremiyetin de sağlanması gibi görünmektedir. Satış ve reklamları sosyal medya platformlarında yapılan helal tatil evleri, genellikle bahçeli villa konseptinde olup içerisinde özel yüzme havuzları, jakuzi, iç havuzlu jakuzi gibi üst sınıfın beğenilerini yansıtan özelliklere sahiptir." Öte yandan, villanın herhangi bir yerden görünmediğine dair söylemlerle, kişilere mahremiyetin korunması garantisi de verilmektedir. Tatilin bir boş zaman etkinliği olması, neticede, onu tüketimin konusu haline getirmektedir. Zira kapitalizm için hedef, her tür tüketici konumdaki bireyin boş zamanını ele geçirerek maksatlı kullanıma açmak ve bu yolda yeni değerler yaratmaktır (Aytaç, 2006, s. 28). Tam da bu sebeple, boş zamanın tüketilmesinde dinsellik bir araç haline gelmekte ve böylece, değerlerin metalaşması söz konusu olmaktadır.

Sosyal medyada giyim ve turizm dışında din ile ilişkili ya da ilişkilendirilmiş çok çeşitli ürün ve hizmet sunan sayfalar bulunmaktadır. Bunların içerisinde sünnet, kına, düğün, bebek mevlidi gibi etkinlikleri, dini öğeler ile eklemleyen İslami organizasyon sayfaları da yer almaktadır. Firmalar, yapılan organizasyonları video ve resim ile sosyal medyada paylaşmakta ve \#bebekanneleri, \#bebekmevlidi, \#islamidüğün, \#islamisünnet, \#bayanilahigrubu gibi hashtagler ile daha fazla insana ulaşma gayesiyle reklamlarını yapmaktadır. Bu anlamda, sosyal medyada önemli bir pazarlama stratejisi olan hashtag kullanımı, ihtiyaç algısını yönlendirmekte ve kitlelere yapay ihtiyaçların temel ihtiyaçmışçasına sunulmasına yol açmaktadır. Marcuse'un (1990) Tek Boyutlu Insan yaklaşımından yola çıkarak, sosyal medyadaki pazarlama stratejilerinin, sistemin tüketimi rasyonalize etme çabasından kaynaklandığı söylenebilir. Öte yandan organizasyonlar sosyal medya hesaplarında, taht kurulumu, masa süsleme, beşik kurulumu, kaz tüyleriyle giriş, üç hoca, ney dinletisi, deflerle ilahiler, bebek şiirleri, mevlidi şerif, Kur'an-ı Kerim tilaveti, program yönetimi gibi hizmetleri belirterek, her ne kadar dini bir görünüm sergiliyor gibi görünseler de, içerik olarak kişinin statüsünü vurgulayan gösterişi ön plana çıkarmaktadır. Böylece bebek mevlitlerinin içeriğinin, batıda yaygınlaşan ve baby shower adı verilen bebek partilerinden bir farkı olmadığı dikkati çekmektedir. Bu durum, Müslümanların medya aracılı̆̆ıyla küresel değerlere entegrasyonuna ilişkin önemli bir izlenim ortaya koyar. Zira kitle iletişim araçları başta olmak üzere teknoloji alanında yaşanan gelişmeler başka kültür ve değerler hakkında bilgi sahibi olunmasını kolaylaştırırken; aynı zamanda, benzer malların dünyanın dört bir yanında tüketilmesini de olanaklı hale getirmektedir. Özetle, zaman ve mekân sınırlamalarının aşıldığı noktada dünya, Marshall McLuhan'ın (1988) belirttiği üzere küresel köy'e dönüșmüș ve kültürel ilișkiler giderek yoğunlaşmıștır. Bu bağlamda yeni medyanın gelișmesi, tüketim kaIıpları başta olmak üzere batılı kültürel kodların görünürlüğünü artırmakla birlikte batılı yaşam pratiklerinin de kolayca benimsenmesine yol açabilmekte ve sosyal medyada dini hassasiyetlerin geri planda bırakıldığı görünümleri yaratabilmektedir.

\subsection{Dini Sembol ve Ürünlerin Tüketimi}

Sosyal medya platformlarında Yasin-i Şerif, Kur’an-ı Kerim, Ayet-el Kürsi, tesbih gibi dini semboller ve anlamlar, Hediyelik Eşya veya Söz ve Mevlid Ürünleri adı altında satılmaktadır. Böylece, bu sayfalarda dini sembollerin özel günlerde kişilere verilen bir "hediye" ya da "hatıra" anlamı taşıyarak tüketim nesnesine indirgendiği gözlemlenmektedir (Bakar, vd. 2013; Zitkiene, 2019; Beaudoin, 2007). Söz konusu sayfaların içeriğine bakıldığında, kişi sayısına göre fiyatların çeşitlendiği ve farklı renk, isme özel seçenekler ile ürünlerin kişiselleştirildiği görülmektedir. ${ }^{12}$ Diğer sayfalarda olduğu gibi, "müșteri memnuniyeti” adı altında, hikâyelerde ve ana sayfada 
tüketici yorumlarına yer verilerek tüketicide güven duygusu yaratmaya yönelik çeşitli stratejiler uygulanmaktadır. Ürün satışı yapan sayfalarda göze çarpan bir diğer husus ise dini içerikli ürünler ile kutsal olmayan ürünlerin kampanya dahilinde bir arada satılmasıdır. Mesela, anneler günü için seccade ile kolyenin bir arada kampanyalı satışa sunulduğu örnekler, sosyal medyada nesnelerin, gösterisel bir boyutta, gerçek anlam ve değerinden farklı bir anlam yüklenerek kitlelere yansıtıldığını ortaya koymaktadır. Baudrillard'ın (2018, s. 160) "gerçeklik tüketiciyi ikna etme uğruna yeniden biçimlendirilir” sözünden yola çıkılarak, dini anlamlara ilişkin hakikatin de dijital ortamlarda yeniden inşa edildiği söylenebilir. Yeni medyanın tüketiciyi gösteri ile aşırı büyüleme imkanına sahip olması, bu ortamların giderek tüketimin önemli bir mekânı haline gelmesine neden olmaktadır. Zira, insanın gösterisel bir ortamda giderek gerçeklikle temasını yitirmesi, ihtiyaç duymadığı ve alamayacağı şeyleri alma zaafını da beraberinde getirmektedir (Ritzer, 2016, s. 234).

Bir diğer önemli nokta ise, yeni medyada dini anlam ve sembollerin, sanatsal ve edebi biçimde varlık bulmasıyla, kutsal değerlerin popüler kültürün malzemesi haline gelmesidir. Tüketim toplumunda birey, nesnelere bağlanarak bir meta fetişizmi sergileyebilmekte, manevi/duygusal boşluğunu ve ihtiyaçlarını da metalar aracılığı ile doldurmaya yönelebilmekte, bu amaçla kutsal aş,, ilahi aşk gibi kavramları da kullanabilmektedir (Sezgin, 2013, s. 123). Örneğin, sosyal medya paylaşımlarında Mevlânâ'nın, "özlü söz" ve "kişisel gelişim"in bir parçası olarak ele alınması ya da onun sema ve ney'ini ön plana çıkarıp derin teemmüli/tefekküri dünyasının ikinci plana atılıyor olması, tüketim kültürünün ürünü olarak değerlendirilebilir (Cebecioğlu, 2007, s. 10-11). Bu yönde dini değerler, tüketimin birer parçası haline getirilmektedir ki; söz konusu öğeler, inancın unsuru olmaktan çıkarak pazarın koşulları ve isteklerine göre şekillenen formlar kazanır. Dolayısıyla, Adorno'nun (2013, s. 67) kültürün uzlaşmaz iki öğesi olarak gördüğü sanat ve eğlence gibi, dini değerler de kültür endüstrisinin bütünselliğine tabi kılınır. Kültür endüstrisi bağlamında değerlendirildiğinde, insanlar gerçek yaşamın sorunlarından eğlence ile uzaklaştırılmakta ve mutluluğun vaat edildiği kurgusal bir arka planla kutsal olan giderek etkisini kaybetmektedir. Sonuçta, birey merkezli paradigma, kapitalist sistemin desteklediği tüketim ideolojisinin dinle girdiği ciddi etkileşimi açıklar gibi görünmektedir.

\section{Sonuç}

Din ve dindarlık konusu tüketim kültürü paradigmasının gölgesinde daha tartışmalı ve karmaşık bir hâl almaya başlamıştır. Bu gelişmede ekonomik, siyasal ve kültürel faktörler kadar, medyanın da payı bulunmaktadır. Özellikle, tüketmenin ötesinde tükettiğini gösterme arzusunun ön planda tutulduğu ve var olmayanın adeta yok kabul edildiği sosyal paylaşım platformlarından dindar kesim de etkilenmektedir. Piyasa ekonomisini önceleyen medya araçlarının yarattığı etkinin, sadece dindarlık boyutunda kalmadığı, dine ve onun değerlerine de yöneldiği açıktır.

Bu bağlamda ekseriyetle yeni medyada, dindar kesimden bireyleri de içerisine alarak yaygınlaşan gösterişçi tüketime yönelik paylaşımlar, hem medya kültürünün toplumun genelinde bulduğu karşıllı̆̆a işaret etmekte hem de bireyler tarafından tüketim ideolojisinin ne derece merkeze yerleştiğini göstermektedir. Tüketim kültürünün benimsenmesi ile birey, tüketerek kendisini diğerlerinden farklılaştırma çabasına girmektedir. Tüketimin dindar bireyler içerisinde de bir prestij, sınıf ve statü konusu haline gelmeye başlaması; onların, tesettür modası, lüks bebek partileri ve helal tatil evleri gibi pratiklere yönelmelerine sebebiyet vermektedir. Bu durum, hac ve umre turizmi örneğinde olduğu gibi firmaları, üst sınıfı hedef alan ve ibadeti sınıfsal bir ayrıma uğratan satış stratejilerine yöneltmektedir. Sonuçta kültür, alt ögeleri içermekle birlikte genel anlamda bütünsel bir olgu olduğu için din de kültürün önemli bir parçası olarak bütünsel olanın değişiminden büyük ölçüde etkilenmektedir. Zira kültürün yapısal ögeleri değişirken alt ögelerinin etkilenmemesini beklemek gerçek dışı olacaktır. Dolayısıyla tüketim, medya ve din üçlüsünün herhangi birindeki değişimin diğerlerindeki az ya da çok değişimi tetikleyeceği öngörülebilir. Bu ise tüketim ekseninde ilerletilecek medya 
ve din ilişkisi çözümlemelerinde, karşılıklı etkileşimin hesaba katılması gerektiği sonucunu doğurmaktadır. Etkilenme tek yönlü olmayıp bu gelişmeler, dini kültürün piyasaya etkisi olarak da okunmalıdır. Dinin gündelik hayat pratiklerine aktarımı, bireylerin kültürel, sınıfsal, ekonomik hatta siyasi konumlanmalarına göre şekillendiği için bu mecralara hâkim olan tüketim ve teşhir kültürüne adapte olan bireylerin, kendi din yorumlarını üretiyor olmaları da konunun bir başka yönüdür.

Tüketim toplumunda değişen ve dönüşen istekler ile dini bayramların, mevlitlerin birer tatil ve eğlence unsuru haline gelmesi, dijital ortamlarda yeni girişimcilik örneklerinin ortaya çıkmasına neden olmaktadır. Özellikle, helal gibi dini kavramlar üzerinden geliştirilen yeni iş imkanları, insanlar için önemli bir gelir kaynağı olmakta ve böylece, kavramın genişletilmesi işlevsel bir boyut kazanabilmektedir. Ancak, bu durumun bir diğer boyutu ise dini anlamların piyasa mantığı içerisinde yer alması sebebiyle onların metalaşmasına yol açabilmesidir. Öte yandan, dini kavramlara ürün ya da hizmet içerisinde yer verilmesi, aşırı tüketim ya da dinen uygun olmadığı düşünülen tüketim pratiklerinin kitleler tarafından normalleştirilmesine neden olabilmektedir ki bu durum, medyada dinin araçsallaştırıldığı yönünde okunabilir. Neticede gerek medya kültürünün, gerekse tüketim kültürünün bilinçli bir şekilde özümsendiği ve bireyin kendisini gerçekleştirmek amacıyla dini değerleri göz ardı edebileceği gerçeği, medya etkisini güçlendirmektedir. Medyanın, insanların davranış ve düşüncelerini etkilediği ve onlara farklı deneyimler sunduğu bir gerçektir. Bu anlamda, sosyal medyada lüks tüketime atfedilen değer, kimliğin dönüşümü ve yeniden üretilmesi noktasında stratejik bir tutum olarak gösterilebilir. Tam da bu sebeple, tüketerek ve sergileyerek var olma durumunun esas olduğu sosyal medyada, dindarlığın dönüşümü tüketim pratikleriyle yansımaktadır.

Sonuç olarak medya, din ve dindarlığın dönüşümündeki başlıca etken olmamakla birlikte dönüşümü hızlandırıcı bir araçtır. Kültürün metaya indirgendiği postmodern toplumda, dinin de anlam ve sembollerinin medya aracilığıyla nesneleşmekte olduğu görülmektedir. Başka bir ifadeyle, teknolojinin dayandığı ekonomik işleyiş içerisinde birey, sisteme daha bağımlı hale gelmekte ve sahip olunan değerler de bu sistem içerisinde tüketilmektedir. Yeni medya ve tüketim ilişkisinde din ve dindarlık da bu noktada problemli hale gelmektedir. Bu sebeple, tekno olumlayıcı çerçevede medyanın sadece hayatı kolaylaştıran bir araç olarak ele alınması, eksik bir bakış açısı oluşturacaktır. Tüketim ve din olgularının karşılıklı bir etkileşime girdiği, bu etkileşimde dinin yeni bir tüketim piyasasına ilham verdiği gerçeği göz ardı edilmemelidir. Piyasanın, giyim, kuşam, eğlence ve boş zaman etkinlikleri üzerinden tüketim alışkanlıkları oluşturarak, insanların gündelik hayatının tamamına, oradan da bir bakıma hayat felsefelerine etki eden bir perspektif değişimini ürettiği belirtilmelidir. Son tahlilde gösterişçi ve hedonistik tüketimin aşılandığı, narsistik eğilimlerin ve teşhirin normalleştirildiği yeni medyada, din ve tüketim ilişkisinin daha kapsamlı çalışııması bir zorunluluk olarak kendini göstermektedir. Dileğimiz, bu araştırmanın, söz konusu alandaki literatüre küçük de olsa bir katkı sunmasıdır.

\footnotetext{
Son Notlar

'Endonezya'da her yıl düzenli olarak gerçekleștirilen Maya Film Ödülleri (Piala Maya), Oscar ödüllerine benzemekte olup başarılı bulunan filmler ve oyuncular onurlandırılmaktadır. Filmde başrol oyuncusu olan Morgan Oey, performansı ile 2015 yılında en iyi çıkış yapan oyuncu ödülüne layık görülmüştür.

${ }^{2}$ http://pinterest/com/pin/393853929891157486.

3 https://www.kisa.link/O4Sk.

${ }^{4}$ Örneğin Selisha.de sitesinde ürünlerin satıșı, açık arttırma sistemine göre gerçekleştirilmektedir. Bu durumun, genel olarak yaratacağı kaygı karşısında, açık arttırmanın dini açıdan bir sakıncası olmadığına yönelik İslam alimlerinin fetvalarına yer verilmiş ve sitede duyurusu yapılmıştır (Timetürk, 2013). ${ }^{5}$ https://muslimwalk.com.

${ }^{6}$ Bu kavram İngilizce "digital opinion leaders" olarak ifade edilmekte, DOLs olarak kısaltılmakta ve daha ziyade iktisat ve pazarlama teorilerinde tüketicileri yönlendiren ve bugün "influencer" kavramıyla da ifade edilen bir anlam taşmaktadır. Mesela bkz. (Merwe ve Heerden (2009). Finding and uti-
} 
lizing opinion leaders: Social networks and the power of relationships, South African Journal of Business Management, 40(3), p. 65-76).

7 Tesettür firmalarının seküler yaşam tarzı ürettiğine yönelik bulgular için bkz. (Gökarıksel ve Secor, 2009; Sandıkçı ve Ger, 2010; Ökten, 2019; Gazneli, 2020; Gazneli ve Sofuoğlu Kılıç, 2020).

${ }^{8}$ Hollanda'da yaşayan Türk iş adamı Taner Tabak tarafından 2010 yılında çıkartılan Kevser Şarapları, gerek isminden dolayı gerekse Müslümanları alkole teşvik etmesiyle büyük bir tepki toplamıştır (haberler.com, 2015).

9 https://instagram.com/amadeturizm?igshid=9xvcj6fu88hnt.

${ }^{10}$ www.facebook.com/326821921281267/posts/467098540586937/.

${ }^{11}$ https://www.milligazete.com.tr/haber/3388655/muhafazakar-tatil-keyfini-helal-tatil-evlerinde-yasayin.

${ }^{12}$ https://instagram.com/mevlidcibasi?igshid=nq5x6omugjsn. 


\section{Kaynakça}

Adji, A. N. (2019). Assalamualaikum beijing repackaged: Habitus, symbolic power and Indonesian cultural production, Makara Hubs-Asia, 23(2), 161-171.

Adorno, T. W. (2013). Kültür endüstrisi-Kültür yönetimi (Çev. N. Ülner, M. Tüzel ve E. Gen). İstanbul: iletişim Yayınları.

Alikılıç, í. ve Özkan, B. (2018). Bir sosyal medya pazarlama trendi, hatırlı pazarlama ve etkileyiciler: Instagram fenomenleri üzerine bir araştırma. Uluslararası Sosyal Bilimler Dergisi, 43-57.

Althusser, L. (2017). İdeoloji ve devletin ideolojik aygıtları (Çev. A. Tümertekin). (6. baskı). İstanbul: İthaki Yayınları.

Aytaç, Ö. (2006). Tüketimcilik ve metalaşma kıskacında boş zaman. Kocaeli Üniversitesi Sosyal Bilimler Üniversitesi Dergisi, 27-53.

Bakar, A., Lee, R. and Rungie, C. (2013). The effects of religious symbols in product packaging on Muslim consumer responses, Australasian Marketing Journal (AMJ), 21(3), 198-204.

Baltacı, A. (2019). Muhafazakar tüketim: Türkiye'de muhafazakarlığın tüketim eksenli dönüşüm dinamikleri, Harran Üniversitesi İlahiyat Fakültesi Dergisi, 24(42), 111-135.

Baudrillard, J. (2011). Simulakrlar ve simülasyon (Çev. O. Adanır). Ankara: Doğu Batı yayınları.

Baudrillard, J. (2018). Tüketim toplumu (Çev. N.T. - F. Keskin). İstanbul: Ayrıntı Yayınları.

Bauman, Z. (2017). Akışkan modernite (Çev. S. O. Çavuş). İstanbul: Can Sanat Yayınları.

Beaudoin, T. (2007). Consuming faith: Integrating who we are with what we buy. Rowman\&Littlefield. Erişim: https://books.google.com.tr/books?id=j3sLTayPVVgC\&pg=PA15\&hl=tr\&source=gbs_toc_r\&cad $=4 \# \mathrm{v}=$ onepage \&q\&f=false

Bocock, R. (2005). Tüketim (Çev. İ. Kutluk). Ankara: Dost Kitabevi.

Bourdieu, P. (2015). Ayrım: Beğeni yargısının toplumsal eleştirisi. Ankara: Heretik Yayınları.

Bourdieu, P. ve L. Wacquant (2016). Düşünümsel bir antropoloji için cevaplar (Çev. N. Ökten) (8. baskı). İstanbul: iletişim Yayınları.

Cebecioğlu, E. (2007). Hz. Mevlânâ üzerine genel bir değerlendirme. illmî ve Akademik Araştırma Dergisi, 7-12.

Çukadar, M. (2017). Helal gıda konusunda tüketici davranışları. Gaziosmanpaşa Üniversitesi Ziraat Fakültesi Dergisi, 190-200.

Demirezen, i. (2010). Tüketim toplumunun oluşumu ve din ile etkileşimi, Dinbilimleri Akademik Araștırma Dergisi, 10(1), 97-109.

Dereli, M. D. (2019). Dini kimliklerin siber uzamda akışkanlaşması. insan\&toplum, 9(1), 85-115. DOI: 10.12658/M0301

Dereli, M. D. (2020). Sanala veda: Sosyal medya ve dönüşen dindarlık. Ankara: Nobel Yayıncilık.

Diyanet İşleri Başkanlığı (2002). İnanç turizmi günleri raporu, Ankara.

Dural, A. B. (2012). Antonio Gramsci ve hegemonya. Elektronik Sosyal Bilimler Dergisi, 11/39, 309-321. 
Dursun, Z. I. I. (2016). Uluslarötesi birlikten ecdada: Türkçe sözlü İslami hip-hop, Moment Dergi, 3(1), 207-227.

Einstein, M. (2007). Brands of faith: Marketing religion in a commercial age. NewYork: Routledge.

Eren, T. ve Atılgan, K. Ö. (2019). Tesettür giyim ürünlerinde moda liderliği, fiyat ve tüketicilerin dini bağlılığı (dindarlık) arasındaki ilişkinin araştırılması. Çağ Üniversitesi Sosyal Bilimler Dergisi, 43-52.

Featherstone, M. (2013). Postmodernizm ve tüketim Kültürü (Çev. M. Küçük). İstanbul: Ayrıntı Yayınları.

Gazneli, D. (2020). Tüketim toplumu bağlamında Türkiye'de yeni medyanın muhafazakârlığın dönüşümü ve dini değerlerin metalașması üzerine etkisi. Aydın: Adnan Menderes Üniversitesi Sosyal Bilimler Enstitüsü, Yüksek Lisans Tezi.

Gazneli, D. ve Sofuoğlu Kılıç, N. (2020). Tesettürden ölçülü giyime. Muhafazakar Düşünce Dergisi, 16(1), 44-70.

Giddens, A. (2014). Modernite ve bireysel kimlik: Geç modern çağda benlik ve toplum (Çev. Ü. Tatııan) (2. baskı). İstanbul: Say Yayınları.

Göle, N. (2017). Modernist kamusal alan ve i̇slami ahlak. İslam'ın yeni kamusal yüzleri: Bir atölye çalışması içinde (19-41) (5. baskı). İstanbul: Metis Yayıncılık.

Gökarıksel, B. and Secor, A. J. (2009). New transnational geographies of Islamism, capitalism and subjectivity: The veiling-fashion industry in Turkey. Area, 41(1), 6-18.

Gumbri, D. S. and Noor, N. M. (2016). The acceptance level of halal cosmetic products among Malaysian consumers, Handayani, 1-22.

Haberler.com (2015). Gimdes'ten alkolsüz şarap ve bira açıklaması: O da haram, 5 Mayıs 2020 tarihinde https://www.haberler.com sitesinden alınmıştır.

Haenni, P. (2014). Piyasa İslamı: i̇slam suretinde neoliberalizm (Çev. L. Ünsaldı). Ankara: Heretik Yayıncilık.

Harvey, D. (2010). Postmodernliğin durumu (Çev. S. Savran) (5. baskı). İstanbul: Metis Yayıncilık.

Hashim, A. J. and Musa, R. (2014). Factors influencing attitude towards halal cosmetic among young adult urban Muslim women: A focus group analysis. Procedia-Social and Behavioral Sciences, 130, 129-134. https://doi.org/10.1016/j. sbspro.2014.04.016

Hürmeriç, P. ve Baban E. (2012). Simmel, Veblen ve Sombart'ın penceresinden hedonik tüketim: Ütopyada Negotium ve Otium, Global Media Journal TR Edition, 2(4), 87-101.

İmga, O. (2010). Amerika'da din ve devlet: Tarihi ve felsefi temeller. Ankara: Liberte Yayınları.

Incil. https://www.openbible.info/topics/wasting.

Jameson, F. (1994). Postmodernizm ya da geç kapitalizmin kültürel mantığı (Çev. N. Plimer). İstanbul: YKY.

Janmohamed, S. (2018). M Nesli: Yeni Müslüman gençlik . İstanbul: Kaktüs Yayınları.

Kallek, C. (2001). İsraf maddesi. İslam Ansiklopedisi, 23, 178-180.

Kirman, M. A. (2005). Dinin ekonomik modeli küreselleşme sürecinde dine yeni bir yaklaşım, On Dokuz Mayıs Üniversitesi Ilahiyat Fakültesi Dergisi, Sayı: 18-19, 147-161.

Koç, B. (2019). Tüketim toplumunda metalaştırılan dini yeniden okuma önerisi: Bireyin dine yabancılaşması üzerine bir giriş, Bingöl Üniversitesi Illahiyat Fakültesi Dergisi, 13(1), 141-167. DOI: 10.34085/buifd. 554550 
Lacivertdergi (2015). Tesettür modasının globalleşmesi ve dünya modasına etkisi, 18 Aralık 2020 tarihinde http://www.lacivertdergi.com/dosya/2014/08/05/ tesettur-modasinin-globallesmesi-ve-dunya-modasina-etkisi adresinden alınmıştır.

Marcuse, H. (1990). Tek boyutlu insan: ileri işleyim toplumunun ideolojisi üzerine incelemeler (Çev. A. Yardımlı) (2. baskı). İstanbul: İdea Yayınları.

McLuhan M. and McLuhan E. (1988). Laws of media: The new science. Toronto: University of Toronto Press.

Mohezar, S., Zailani, S. and Zainuddin, Z. (2016). Halal cosmetics adoption among young Muslim consumers in Malaysia: Religiosity concern. GJAT, (6)1, 47-59.

Odabaşı, Y. (2017). Tüketim kültürü: Yetinen toplumdan tüketen topluma. İstanbul: Agora Kitaplığı.

Onurlubaş, E. ve Öztürk, D. (2018). Sosyal medya uygulamalarının $Y$ kuşağı satın alma davranışı üzerine etkisi: Instagram örneği. OPUS Uluslararası Toplum Araştırmaları Dergisi, 984-1016.

Ökten, B. (2019). Sanal tesettür mağazalarının sosyal bir olgu olarak tesettür alışkanlıklarındaki değişime etkisi: İstanbul'da üniversite okuyan kız öğrenciler örneği. Akademik Platform Eğitim ve Değişim Dergisi, 2(2), 144168.

Özdemir, Ö. (2011). Yeni dönem İslami sinema ve modernlik-geleneksellik sınırında üslup arayışı, Sinecine, 2(2), 7-31.

Özet, í. (2019). Fatih-Başakșehir: Muhafazakar mahallede iktidar ve dönüşen habitus. İstanbul: Iletişim Yayınları.

Pişkin, M. (2016). Tüketim toplumunda din ve değerler: Lüks hac ve umre örnek olayı, Insan ve Toplum Dergisi, 6(2), 131-154. DOI: dx.doi.org/10.12658/human. society.6.12.M0195

Postman, N. (2017). Televizyon: Öldüren eğlence, gösteri çağında kamusal söylem (Çev. O. Akınhay) (7. baskı). İstanbul: Ayrıntı Yayınları.

Ritzer, G. (2016). Büyüsü bozulmuş dünyayı büyülemek (Çev. F. Payzın) (4. baskı). İstanbul: Ayrıntı Yayınları.

Sandıkçı, Ö. and Ger, G. (2010). Veiling in style: How does a stigmatized practice become fashionable? Journal of Consumer Research, 37(1), 15-36.

Saydan, R. ve Nart, S. (2009). Online tüketimi teşvik: Sanal ortamda tüketici ikna süreci ve belirleyicileri. Öneri Dergisi, 85-94.

Seybert, J. (2004). EPM's guide to the christian marketplace: Selling books, music, gifts and videos to America's 218 million Christians. New York: EPM Communications.

Sezgin, S. (2013). Popüler medyada metalaşmış aşk anlatılarının söylemsel analizi. Ankara: Hacettepe Üniversitesi Sosyal Bilimler Enstitüsü, Yayınlanmamış Yüksek Lisans Tezi.

Simmel, G. (2013). Moda felsefesi: Modern kültürde çatışma (Ed. A. Artun). İstanbul: İletişim Yayınları.

Simmel, G. (2009). Metropol ve zihinsel hayat: Bireysellik ve kültür (Çev. T. Birkan). İstanbul: Metis Yayınları.

Sofuoğlu Kılıç, N. ve Gazneli, D. (2020). Tüketim-din etkileşimi bağlamında sosyolojik bir analiz: Helal kozmetik. Research in Education and Social Science, 339372. İzmir: Duvar Yayınevi. 
Sombart, W. (2013). Aşk, lüks ve kapitalizm (Çev. N. Aça). Ankara: Pharmakon Yayınevi.

Sülün Ergül, H. (2014). Industrialization of religion in halal food consumption. Yayınlanmamış Yüksek Lisans Tezi, İstanbul: Fatih Üniversitesi.

Swartz, D. (2013). Kültür ve iktidar-Pierre Bourdieu'nün sosyolojisi (Çev. D. F. Şannan ve A. G. Berkkurt). Ankara: Heretik Yayınları.

Şahin, I. (2013). Online Alevi topluluklar: Ritüel desenli bir gruptan mit desenli bir inanç topluluğuna. Konya: Çizgi KitabeviYayınları.

Tevrat, https://www.kutsalkitap.org/online-tevrat-oku/

Timetürk, (2013). ilk íslami sanal alışveriş sitesi. 3 Mayıs 2020 tarihinde https://www. timeturk.com sitesinden alınmıştır.

Ulaş, S. (2019). Lüks marka sadakati ve sosyal medya. Ankara: Nobel.

Ülgener, S. F. (1981). Dünü bugünü ile zihniyet ve din: İslam, tasavvuf ve çözülme devri iktisat ahlâkı. İstanbul: Der Yayınevi.

Ünal, A. Z. (2017). Bourdieu'nün tabakalaşma teorisi bağlamında üst sınıftan alt sınıfa doğru hayat tarzı tahakkümü. Uluslararası Sosyal Araştırmalar Dergisi, 49, 380388.

Veblen, T. B. (1899). The theory of the leisure class: An economic study of instutitions. New York: Macmillan.

Veblen, T. B. (2017). Aylak sınıfın teorisi: Kurumların iktisadi incelenmesi (Çev. E. K. - H. Bilir). Ankara: Heretik Yayınları.

Weber, M. (2014). Protestan ahlakı ve kapitalizmin ruhu (Çev. M. Ökten). Ankara: Tutku Yayınevi.

Weber, M. (2016). Din sosyolojisi: Max Weber (Çev. L. Boyacı) (2. baskı). İstanbul: Yarın Yayınları.

Yıldız, S. ve Yıldız, Z. (2018) İslam'ın turizme yansıması: Helal turizm, Mehmet Akif Ersoy Üniversitesi Sosyal Bilimler Enstitüsü Dergisi, 10(26), 770-781.

Yüce Kur'an ve açılklamalı yorumlu meali. (2011). Çev. A. Şener, M. C. Sofuoğlu, M. Yıldırım. Ankara: Türkiye Diyanet Vakfı Yayınevi.

Yeniçıktı, N. (2014). iletişimsel eylem ve Facebook: Gezi Parkı olaylarında sosyal medyanın gücü, Selçuk Üniversitesi Illetişim Fakültesi Dergisi, 8(2), 263-284.

Zitkiene, R. and Kriaučiūnaitè-Lazauskienè, G. (2019). The interplay of religious symbols and cultural values theory in advertising, Sciendo, 81(1), 119-137. 


\title{
MEDIAD \\ Medya ve Din Araştırmaları Dergisi | Journal of Media and Religion Studies
}

\section{Appearances of Religion-Based Consumption in the New Media: An Assessment in the Context of Consumption Culture}

\author{
Didem GAZNELI \\ Nilgün SOFUOĞLU KILIÇ
}

\section{Extended Abstract}

It is possible to see the cultural reflections of the consumer society all over the world since the 1950s. At this point, it can be said that with the early development of modern capitalism, there is a transition from its approach to consumption. In this context, it would not be wrong to define the consumption culture created by the consumption society as a culture imposed on the masses in order to ensure the continuity of the capitalist system. It is essential that the system develops various mechanisms such as credit cards, online shopping opportunities, and the creation of young and child consumers, and the policy of controlling consumption and keeping the individual in the system is essential. At this point, the power of media platforms cannot be denied. Ultimately, with the effect of the developments in mass media, consumption has become an important factor that defines the identity of the individual; as well as coinciding with the theories of critical theory, it has been the subject of an important problematic of the social with its commodification dimension.

In this direction, while areas of expertise such as mass media and advertising sector encode the minds of the masses with consumption; It shapes new consumption patterns and experiences by establishing a consumption understanding in the direction of "consume what is shown, show what is consumed". Considering the profound effect of the media on the masses, it can be said that the lifestyle and consumption patterns offered through programs and advertisements reinforce hedonistic consumption. Viewers connect with the people they see on the screen and want to be like them. In short; the clothes worn by the celebrities, the food they eat and the places they visit, push the individual into the effort of being "that" person, pushing them into consumption. In this direction, orientation towards the consumed product finds meaning through the symbolic value of the product. Today, the increase in the number of intermediaries that facilitate consumption and the diversification in consumption places have an effect on the acceleration of consumption culture all over the world. In this sense, it is a fact that digital environments, which enable the individual to be included in consumption without being subject to time constraints and spatial restrictions, have become an important consumption place and direct consumption. As a result, it is seen that in the consumer society where consumption expands in the leisure time of the individual, the media instill universal consumption habits all over the world and intensify the intertwining of local values and global values. However, in these environments where consumed products become indicators of status, the inequalities created by my consumption society deepen and reproduce. On the other hand, in digital environments where users are active and produce informa- 
tion, the meaning is made ordinary by combining the message with intense visuality and entertainment. Especially in social media platforms, it is encouraged that the individual's perception of beauty and body is transformed and the body should be sexualized with the exhibition culture through the signs. Thus, in the consumption society based on the interrelationality of production and consumption, the individual, on the one hand, produces his relations and himself by consuming through the media, on the other hand he consumes himself and his values in a system in which he is constantly in competition.

On the other hand, the expansion of capitalism does not only reveal consumption-oriented lifestyles, but also causes some cultural transformations that lead to the formation of religion according to capitalism. In this sense, the results of the modern world that cannot be limited to the economic field affect the field of values by creating mental transformations on the individual. Therefore, the moral system in the nature of Calvinism, that is, religion in a broader sense, which Weber emphasized and which led to the development of capitalism, now takes place in a structure that capitalism shapes itself. The positioning of religion in the logic of the market leads to variations both in the meaning of religious products and symbols and in the way of living religiousness. In short, with the introduction of consumer culture into the religious field, it is now possible to come across companies that transform the Hajj visit into a holiday atmosphere with VIP services, as well as individuals who add fashion to their lives by adding veiling. In this context, it should be said that the media also affects culturally religious individuals. As a matter of fact, religious values are confronted with the values of the media, with the increasing concern about the image in social media, the fragmentation of privacy with exaggerated posts, and consumption becoming an indicator of status. However, it would be an incomplete assessment to define the main cause of the controversial views on religion and religiosity today as the media. Considering the fact that the media is a tool and consumption has deeper meanings than purchasing, it should be said that the effects of economic, social and cultural transformations and their manifestations are reflected in the media. At this point, the media accelerates the transformation in the world of meaning in terms of integrating the masses into the system, adopting the cultural values of the West, and building the individual suitable for its own discourse in a broader sense. For this very reason, the relationship of religion with the media and its reflections are the target of intense discussions.

As a result, with the media becoming a part of our daily life, people demand religiousness from these environments and the religion-media relationship develops. In this sense, the structure of digital media can often work against the sanctity of religion, and consequently, the sacred's effort to create itself in the postmodern society can turn into a problematic. In this context, media are environments where religious meanings are also discussed on the basis of economic concerns. Not only the individual's consumption dimension, but also the consumption of values, lays the groundwork for another debate that is directed towards the media. Because, in the logic of the market, the inclusion of religious concepts in the media can gain a functional meaning by providing new job opportunities to individuals, on the other hand, it accelerates the process of commodification of values through economic gain by attracting religious individuals to consumption. This situation makes the role of the media in the relationship between religion and consumption more complex and controversial.

Bu makale iThenticate yazılımıyla taranmıştır. İntihal tespit edilmemiştir. This article has been scanned by iThenticate. No plagiarism detected.

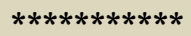

Bu çalışmada “Yükseköğretim Kurumları Bilimsel Araştırma ve Yayın Etiği Yönergesi” kapsamında uyulması belirtilen kurallara uyulmuştur.

In this study, the rules stated in the "Higher Education Institutions Scientific Research and Publication Ethics Directive" were followed. 